\title{
Assessment of Paint Layers Quality 2. Identification of biological species grown on a railway bridge
}

\author{
NICOLETA OANA NICULA (BUTOI) ${ }^{1}$, EMESE VARGA ${ }^{2}$, ADRIANA MARIANA BORS ${ }^{3 *}$, IOSIF LINGVAY ${ }^{1}$ \\ 1.National Institute for Research and Development in Electrical Engineering INCDIE ICPE-CA, 313, Splaiul Unirii, 030138, Bucharest, \\ Romania \\ 2.Hungarian Railways Co., Regional Infrastructure Directorate of Szeged, Regional Management Support, 6720 Szeged, Tisza \\ Lajos krt. 28-30, Hungary \\ 3.ICPE SA, 313 Splaiul Unirii, 030138, Bucharest, Romania
}

\begin{abstract}
The species from the increased biofouling on the paint layers applied to the metallic strength structure of a railway bridge located in a Natura 2000 protected area have been identified by specific biologic and microbiological methods. As a result of the analysis of the biological samples taken on the field, it has been found that relatively large variety of filamentous molds are present (Aspergillus fumigatus, Asprgillus flavus, Aspergillus niger, Paecilomyces variotii, Chaetomium globosum, Trichoderma viride, Stachybotris atra, Trichoderma sp., Alternaria sp and Penicillium sp.). Samples also show, lichens (Xanthoria parietina and Hypogymnia physodes) and lower plants capable of photosynthesis such as algae (Chlorophyta Xanthophyceae, Chrysophyceae) and moss (Lunularia cruciata, Marchantiophyta).
\end{abstract}

Keywords: paint coat, filamentous molds, lichens, algae, moss

The issue of sustainability and safety in exploitation of metallic structures of resistance, especially of bridges, is complex and with practical, economic and ecological implications - which can be decisive for the future of mankind [1].

The safety in exploitation of bridges is given by the resistance to mechanical stress (application specifics) of the materials (usually rolled steel and / or reinforced concrete) from which they are made.

The metal structure of bridges is exposed to degradation by corrosion due to both climatic stresses and aggressive agents in the atmosphere (humidity, $\mathrm{O}_{2}, \mathrm{CO}_{2}$, as well as pollutants such as $\mathrm{SO}_{2}, \mathrm{NO}_{x^{\prime}}$ etc.).

In these conditions, the durability and the safety of bridges is largely disturbed by the quality and resistance to the action of environmental factors (atmospheric weather, aggressive pollutants from the atmosphere, micro- and macro-biological factors, solar radiation - especially in the UV spectrum [2-18] and / or some fatty substances [1923]), of the polymeric finishing materials applied to the strength structure for anticorrosion protection (usually paint film - polymer composites with the addition of various ingredients and colour pigments).

The results of field investigations carried outon a railway bridge were presented in [24], which showed that the relatively recent applied paint layers (1983) resulted in massive increases in microbiological species (filamentous molds, moss, lichens and algae), respectively over $10 \%$ of the surface is covered by biofouling.

Under the biodegradable paint layers, the corrosion of the metal support is substantially accelerated by microbiological corrosion [25-34]

Usually, preventing the formation of biofouling on the paint layers is accomplished either by using suitable materials (resistant to the action of microorganisms) or by adding to paintand / or applying to the paint layer of biocidal materials to prevent the biological species growth [35 41].

Selecting resistant paints against biofouling and / or suitable antifouling biocide materials requires knowledge of the biological species that affect the paint layers under actual operating conditions. It is noted that both the production and use of biocidal materials usually have a negative impact on the environment (especially persistent pollutants are dispersed [42-44]) - with hardly foreseeable implications for the environment [45-47].

In order to prevent pollution of the environment all factors (water, soil $[48,49]$ ) it is necessary to use them rationally and to develop adequate decontamination methods [50].

In this context, the work purpose is to identify in the laboratory experiments the biological species from the samples taken from the field on a railway bridge (with the paint layers degraded following the massive increases of biofouling [24]).

\section{Experimental part}

In order to identify biological species - grown after approx. 4 years after repainting a railway bridge [24] biomass samples were taken into sterile bottles. The bridge crosses the Tisza River (including its basin flood) and is located in a Natura 2000 protected area [24].
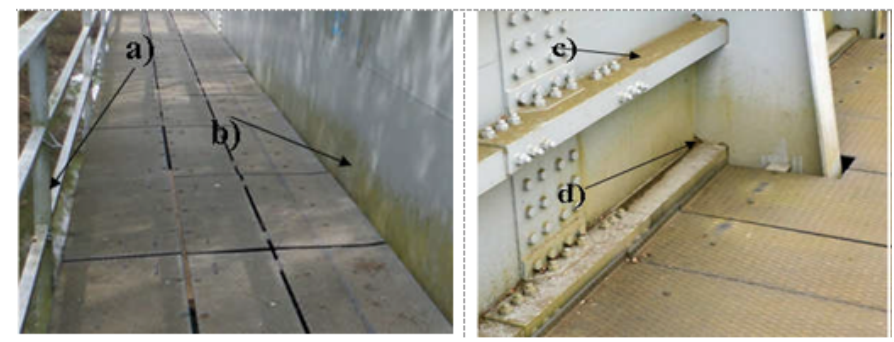

Fig. 1. Biological samples a), b), c) and d) - the place of sampling

In figure 1 there is an overview of the analysed biofouling and locations of sampling.

To identify the biological species of moss, algae and fern type, microscopic images with a USB, 025 USB type microscope (China) were captured from representative areas.

In order to identify the present mold species, inoculum saline was prepared byultrasonography ( $5 \mathrm{~min}$ ) of approx.

*email: adrianambors@gmail.com; Phone: 0773917319 
$2 \mathrm{~g}$ of biological sample taken from the field (from the biofouling areas of Fig. 1) in $50 \mathrm{~mL}$ of a solution having $2 \mathrm{~g}$ sodium nitrate ( $\left.\mathrm{NaNO}_{3}\right), 0.7 \mathrm{~g}$ monopotassium phosphate $\left(\mathrm{KH}_{2} \mathrm{PO}_{4}\right), 0.5 \mathrm{~g}$ potassium chloride $(\mathrm{KCl}), 0.5 \mathrm{~g}$ Magnesium sulphate heptahydrate $\left(\mathrm{MgSO}_{4} \cdot 7 \mathrm{H}_{2} \mathrm{O}\right), 0.3 \mathrm{~g}$ dipotassium phosphate $\left(\mathrm{K}_{2} \mathrm{HPO}_{4}\right)$ and $0.01 \mathrm{~g}^{4}$ iron (II) sulphate $\left(\mathrm{FeSO}_{4}\right)$ dissolved in $1[$ of bidistilled water.

The suspension obtained was separated by decantation - the liquid, transparent phase being used to inoculate microbiological samples on Czapek-Dox culture media.

The Czapek-Dox culture medium was prepared [51] by adding $1000 \mathrm{~mL}$ of saline solution of $30 \mathrm{~g}$ of sucrose and $40 \mathrm{~g}$ of agar-agar.

After dissolving the sucrose and the agar-agar added (with stirring at $60 \pm 5^{\circ} \mathrm{C}$ ), the culture medium obtained was sterilized in the autoclave at $110 \pm 3^{\circ} \mathrm{C}$ for $30 \mathrm{~min}$.

About $10 \mathrm{~mL}$ of the sterilized culture medium was poured into Petri dishes and, after cooling to ambient temperature, gelling was sprayed with approx. $1 \mathrm{~mL}$ of inoculum saline solution.

The microbiological samples thus obtained were incubated for 7 days in a controlled atmosphere $\left(30 \pm 2^{\circ} \mathrm{C}\right.$, $90 \pm 5 \% \mathrm{RH}$ ).

Microbiological materials were selectively sampled from the mold mix, with which new subculturing samples were inoculated for the purpose of species separation and identification.

Species identification was made after 7 days of incubation of subculturing samples by observations on stereomicroscope (type IOR - Romania).

\section{Results and discussions}

Representative images captured with the USB microscope on the biofouling paint samples taken from the field are shown in figure $2-6$.

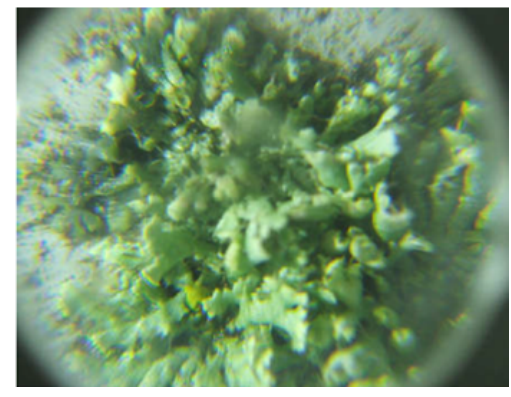

Fig. 2. Microscope image $x$ 100 - where moss is predominantly Lunularia cruciata (Marchantiophyta)

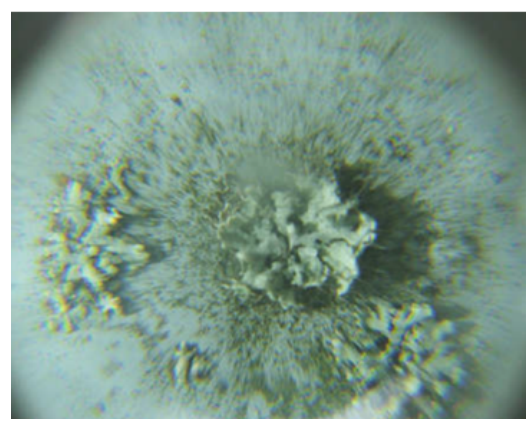

Fig. 3. Microscope image $x 10$ - besides algae and moss, the lichen Hypogymnia physodes is observed

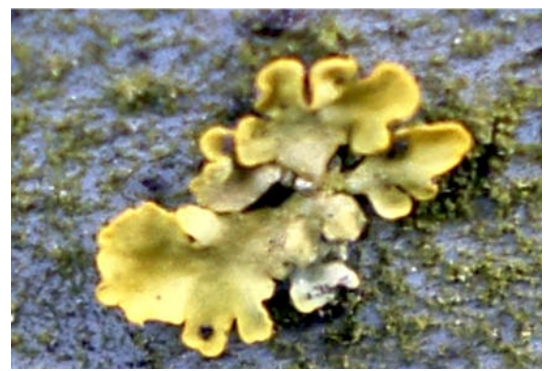

Fig. 4. Microscope image x 10 - Besides microalgae and moss, the lichen Xanthoria parietina is noticed

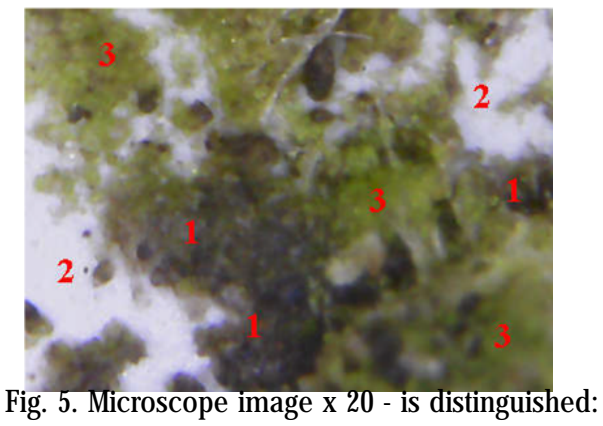

1 - increases of Aspergillus Niger; 2 - Mixed colonies of Aspergillus fumigatus and Chaetomium globossum; 3 - algae

Chlorophyta Xanthophyceae, Chrysophyceae

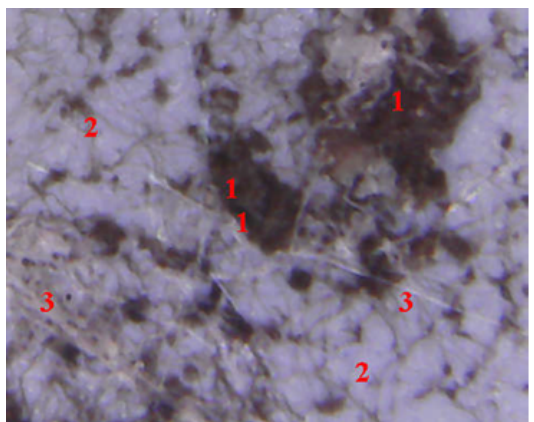

Fig. 6. Microscope image x 100: 1 - increases of Aspergillus Niger;

2 - increases in Chaetomium globosum; 3 - well-developed mycelium / filaments

From the analysis of figures $2-6$. it is noted that on the support of mold colonies (predominantly Aspergillus niger, Chaetomium globossum and Aspergillus fumigatus), the layer (top coat) paint shows increases of moss specific to the area (Lunularia cruciata) and Lichens (Xanthoria parietina and Hypogymnia physodes).

These findings are supported by field observations [24].

From the analysis of figure 6 in addition to the expanded colonies of Aspergillus Niger and Chaetomium globossum, it is noted that the micelles (filament growths) are particularly well developed, which can explain the expansion and relative adhesion of the molds on the top coat paint.

On the other hand, the massive mold growth and welldeveloped mycelium indicate a poor resistance of the dyeing material to filamentous molds action.

It is noted that relatively low resistance to filamentous molds action was also found in some sorts of polymer used in underground power cables [31,53] and / or plastic pipelines [54].

By microbiological observations on a stereomicroscope on the samples inoculated with the inoculum solution prepared from the harvested biological samples (biofouling), it was found that the increased molds species are determined by the sampling site (fig. 1).

Representative images of the molds growth ( 7 days of incubation) on the Czapek-Dox culture medium are shown in figure 7.

By analyzing the images in figure 7 (microbiological observations on stereomicroscope) it was found that on each of the incubated samples several species of molds have been observed, visually observable on lamella a Trichoderma sp. and Chaetomium sp.; on lamella b Aspergillus sp., Chaetomium sp., Asprgillus flavus and Stachybotris atra; on lamella c - Alternaria sp., Chaetomium sp. and Aspergillus niger respectively Chaetomium sp., Aspergillus flavus, Paecilomyces variotii and Aspergillus niger, on lamella $\mathrm{d}$.

From the mold growths illustrated in figure 7 , it has been selectively harvested the inoculum material, after which it 


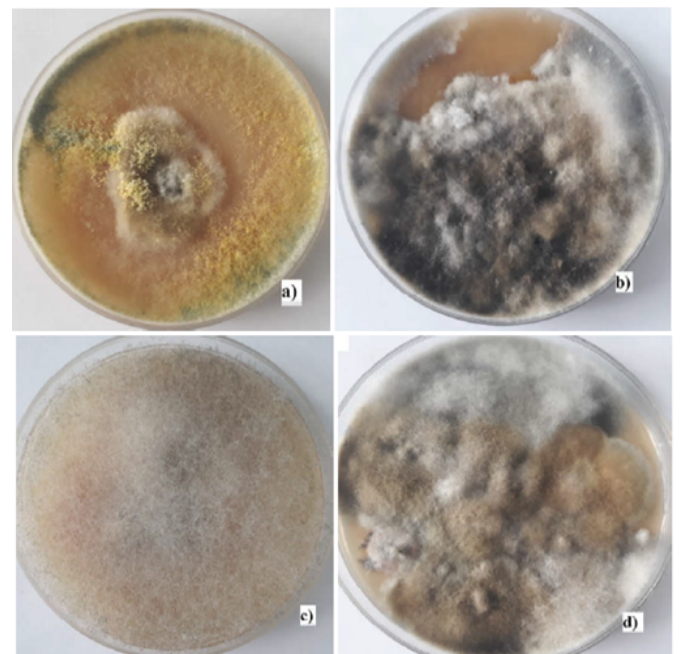

Fig. 7. Growth of mold (7 days of incubation) on Czapek-Dox medium inoculated with inoculum prepared from biofouling

harvested in the field. a), b), c) and d) - the place of sampling (fig. 1)

was used by repeated subculturing, for mold species identifying, (representative images of increases in 7 days of incubation are shown in figure 8 - 11).

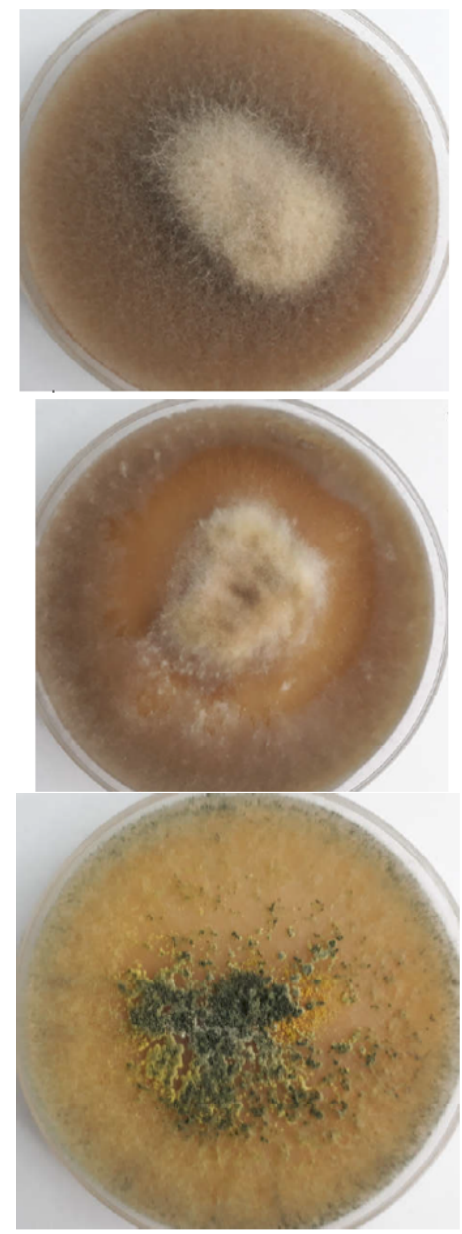

Fig. 8. Aspergillus fumigatus (dominant) and Aspergillus Niger images obtained by sub culturing

Fig. 9. Paecilomyces variotii and Chaetomium globossum images obtained by sub culturing

Fig. 10. Trichoderma viride and Penicillium sp. images obtained by sub culturing

Fig. 11. Chaetomium globossum (dominant) and Aspergillus Niger images obtained by sub culturing
Thus, they have been identified: Aspergillus fumigatus, Asprgillus flavus, Aspergillus Niger, Paecilomyces variotii, Chaetomium globossum, Trichoderma viride, Stachybotris atra, Trichoderma sp., Alternaria sp. and Penicillium sp.

The biological and microbiological investigations results show a hight diversity of biological species grown in the paint layers of a railway bridge.

As result of performed analyzes were found molds (Aspergillus fumigatus, Asprgillus flavus, Aspergillus Niger, Paecilomyces variotii, Chaetomium globossum, Trichoderma viride, Stachybotris atra, Trichoderma sp., Alternaria sp. and Penicillium sp.), lichens (Xanthoria parietina and Hypogymnia physodes), including species capable of photosynthesis such as algae (Chlorophyta Xanthophyceae, Chrysophyceae) and moss (Lunularia cruciata, Marchantiophyta).

It is supposed that certain grow th conditions of lichens, algae and moss have been created by extended colonies of filamentous molds which have the enzymatic apparatus suitable for the polymerization of carbon in polymers [5] and whose filaments penetrate the polymeric paint layers.

In these conditions, the prevention of biofouling growth can be achieved either by the selection and application of high resistance coating materials to natural thermooxidative processes (thermal stress and UV action $[6,13$, $14,16]$ and the molds action $[8,10,15])$, or through the use of appropriate antifungal biocides [35-41] (obviously with the necessary precautions -taking into account that the investigated bridge is in the Natura 2000 protected area [24]).

\section{Conclusions}

By specific biological and microbiological methods, biofouling species have been identified in the layers of paint applied to the metallic strength structure of a railway bridge crossing the Tisa River in Hungary.

Following the analysis of the biological samples taken from the field, the inferior plants presence has been identified, capable of photosynthesis such as algae (Chlorophyta Xanthophyceae, Chrysophyceae) and moss (Lunularia cruciata, Marchantiophyta) were found in addition to a wide variety of filamentous molds (Aspergillus fumigatus, Asprgillus flavus, Aspergillus Niger, Paecilomyces variotii, Chaetomium globossum, Trichoderma viride, Stachybotris atra, Trichoderma sp., Alternaria sp. and Penicillium sp.) and lichens (Xanthoria parietina and Hypogymnia physodes).

Acknowledgment: The authors thank Hungarian State Railways Co. and FORKORR Ltd Hungary for access to the objective and logistical support in carrying out the work. Also thank for funding by the contract type D, no.11384/18.06.2018 (ECO-NANO-ECO)

\section{References}

1. STERE, E.A., POPA, I., Electrotehnica, Electronica, Automatica (EEA), 66, no.3, 2018. pp. 125-136.

2. HUA, J., LI, X., GAO, J., ZHAO, Q., Mater. Des, 30, 2009, pp. 15421547.

3. YANG, X.F., TALLMAN, D.E., BIERWAGEN, G.P., CROLL, S.G., ROHLIK, S., Polymer Degradation and Stability, 77, 2002. pp. 103-109. 4. RUS, T., BORS, A.-M., CARAMITU, A.-R., LINGVAY, I., VAIREANU, D.I., Mat. Plast. 55, no.2, 2018. pp. 167-175.

5. LOREDO-TREVINO, A., GUTIERREZ-SANCHEZ, G., RODRIGUEZHERRERA, R., AGUILAR C.N., J Polym. Environ, 20, 2012, pp. 258-265. 6. RUS, T., LINGVAY, I., CARAMITU, A.-R., BORS, A.M., VAIREANU, D.-I., Mat. Plast., 54, no.4, 2017, pp. 720-725.

7. LEJA, K., LEWANDOWICZ, G., Polish J. of Environ. Stud., 19, no 2, 2010, pp. 255-266. 
8. RUS, T., RADU, E., LINGVAY, I., LINGVAY, M., CIOBOTEA-BARBU, O.C., CAMPUREANU, C., BENGA, F.-M., LAZAR, G.-C., VAIREANU, D.I., U.P.B. Sci. Bull., Series B, 79, no. 4, 2017, pp. 167-180.

9. GNANAVEL, G., VALLI, V.P.M.J., THIRUMARIMURUGAN, M., International J ournal of Pharmaceutical and Chemical Sciences, 1, no. 3, 2012, pp. 670-673.

10. BORS, A.-M., BUTOI, N., CARAMITU, A.-R., MARINESCU, V., LINGVAY, I., Mat. Plast., 54, no.3, 2017. pp. 447-452.

11.SUAREZ-CORRALES, X.I., CORVO-PEREZ, F.E., VILLAR-LOPEZ, R.V., MARRERO, R., Ingeniería Investigación y Tecnología, 15, no.1, 2014, pp. $29-40$.

12.RAVIKUMAR, H.R., RAO S.S., KARIGAR, C.S., Indian J ournal of Science and Technology, 5, no.1, 2012, pp. 1977-1987.

13.RUS, T., CARAMITU, A., MITREA, S., LINGVAY, I., Diagnostic of Electrical Machines and Insulating Systems in Electrical Engineering - DEMISEE 2016, IEEE Xplore, DOI: 10.1109/DEMISEE.2016.7530466, 2016. pp. 60-65.

14.JIANWEN, H., XIAOGANG, L., J IN, G., QUANLIN, Z., Materials and Design, 30, 2009, pp. 1542-1547.

15. CARAMITU, A., BUTOI, N., RUS, T., LUCHIAN, A.-M., MITREA, S., Mat. Plast., 54, no. 2, 2017, pp. 331-337.

16. HU, J., LI, X., GAO, J., ZHAO, Q., Progress in Organic Coatings, 65, 2009, pp. 504-509

17. BUTOI, N., LUCHIAN, A-M. CARAMITU, A., MITREA, S., RUS, T., Electrotehnica, Electronica, Automatica (EEA), 65, no. 1, 2017, pp. 7280.

18.ASHWINI, R., ANCHANA D.C., International Journal of Biology Research, 3, no. 1, 2018, pp. 180-184.

19. RUS,T., CARAMITU, A.R., UNGUREANU, L.C., MARINESCU, V., BORS, A.M., VAIREANU, D.I., Mat. Plast., 55, no. 1, 2018, p. 28-32.

20. LUNGULESCU, E.M., LINGVAY, I., UNGUREANU, L.C., RUS, T., BORS, A.M., Mat. Plast., 55, no. 2, 2018, pp. 201-206.

21. LINGVAY, I., BORS, A.M., UNGUREANU, L.C., STANOI, V., RUS, T., Rev. Chim. (Bucharest), 69, no. 5, 2018, pp. 1139-1144.

22. LINGVAY, I., RUS, T., BORS, A.-M., STANOI, V., UNGUREANU, L.-C., Electrotehnica, Electronica, Automatizari (EEA), Vol. 66 (3), 2018. pp. 58-63

23. LINGVAY, I., UNGUREANU, L.-C., STANOI, V., RUS, T., BORS, A.-M., SZATMARI, I., OPRINA, G., Electrotehnica, Electronica, Automatica (EEA), 65, no. 4, 2017, pp. 117-122.

24.VARGA, E., FORTUNA, L., LINGVAY, D., BORS, A.-M., NICULA (BUTOI), N.O., LINGVAY I., Assessment of paint layers quality. 1 Field investigations on a railway bridge, Mat. Plast., 55, no. 3, 2018, p.320

25. RADU, E., MITREA, S., PATROI, D., VOINA, A., MOSCALIUC, H., LINGVAY, I., IEEExplore, DEMISEE 2016, pp. 38-43.

26. LINGVAY, J., SZATMÁRI, I., PRIOTEASA, P., LINGVAY, M., TUDOSIE, L. M., Korroz. Figy., LIV, no.1, 2014, pp. 15-21.

27. LINGVAY, J., RADU E., MITREA S., LINGVAY M., UDREA O., SZATMÁRI I., Korroz. Figy., LIV, no. 2, 2014, pp. 40-46.

28. SZATMARI, I., TUDOSIE, L.M., COJOCARU, A., LINGVAY, M., PRIOTEASA, P., VISAN, T., U.P.B. Sci. Bull., Series B, 77, no. 3, 2015, pp. 91-102.

29. LINGVAY, I., RUS, G., STOIAN F., LINGVAY, C., UPB Sci. Bull, Series B, 63, no. 3, 2001, pp. 263-270.

30. LINGVAY, I., RUS, G., BURUNTEA, N., UPB Sci. Bull, Series B, 63, no. 3, 2001, pp. 29-36.
31. LINGVAY, I., ÖLLERER, K., LINGVAY, C., HOMAN, C., CIOGESCU, 0., Rev. Chim. (Bucharest), 58, no.7, 2007, p. 624-627.

32. SZATMARI, I., LINGVAY, M., TUDOSIE, L., COJOCARU, A., LINGVAY, I., Rev. Chim. (Bucharest), 66, no. 3, 2015, p. 304-311.

33. LINGVAY J., SZATMARI I., LINGVAY M., TUDOSIE L., Korroz. Figy., LIII, no. 3, 2013, pp. 71-80.

34. PRIOTEASA, P., LINGVAY, M., SZATMARI, I., BURUNTEA, N., LINGVAY, I., Electrotehnica, Electronica, Automatica (EEA), 62, no. 2, 2014, pp. 60-65.

35. CAMARA, B., DE LOS RIOS, A., URIZAL, M., DE BUERGO, M._A., VARAS, M.J., FORT, R., ASCASO, C., Microb. Ecol., 62, 2011, pp. 299313.

36. IENASCU, I.M.C., BALAES, T., PETRE, C.V., POP, R.O., CATA, A., STEFANUT, M.N., ALBU, P., POENARU, M., Rev. Chim. (Bucharest), 69, no. 7, 2018, pp. 1876-1880.

37. FAVERO-LONGO, S.E., BENESPERI, R., BERTUZZI, S., BIANCHI, E., BUFFA, G., GIORDANI, P., LOPPI, S., MALASPINA, P., MATTEUCCI, E., PAOLI, L., RAVERA, S., ROCCARDI, A., SEGIMIRO, A., VANNINI, A., International Biodeterioration \& Biodegradation, 123, 2017, pp. 127137.

38. PICA, A., FICAl, A., Rev. Chim. (Bucharest), 67, no. 1, 2016, pp. 3437.

39. VANNINI, A., CONTARDO, T., PAOLI, L., SCATTONI, M., FAVEROLONGO, S.E., LOPPI, S., International Biodeterioration \& Biodegradation, 129, 2018, pp.189-194.

40. FAVERO-LONGO, S.E., SANDRONE, S., MATTEUCCI, E., APPOLONIA, L., PIERVITTORI, R., Sci. Total Environ., 466, 2014, pp. 26-33.

41. DE LOS RIOS, A., PÉREZ-ORTEGA, S., WIERZCHOS, J., ASCASO, C., Int. Biodeterior. Biodegrad., 67, 2012, pp. 64-72.

42. NEAMTU, S., BORS, A.M., STEFAN, S., Rev. Chim. (Bucharest), 58, no.9, 2007, pp. 938-942.

43. BORS, A.-M., MEGHEA, I., NICOLESCU, A.-M., BORS, A.-G., 12h International Multidisciplinary Scientific Geoconference (SGEM), Albena, Bulgaria, V, 2012, p. 891.

44. BORS, A.M., MEGHEA, A. ESEANU D., NEAMTU, S., LESNIC M., Rev. Chim. (Bucharest), 58, no. 8, 2007, pp. 776-781.

45. STERE, E.A., POPA, I., Electrotehnica, Electronica, Automatica (EEA), 65, no. 1, 2017, pp. 97-102.

46. STERE, E.A., POPA, I., Electrotehnica, Electronica, Automatica (EEA), 65, no. 2, 2017, pp. 163-170.

47. STERE, E.A., POPA, I., Electrotehnica, Electronica, Automatica (EEA), 65, no. 3, 2017, pp. 213-220.

48.MORARIU, S.I., DUCEAC, L.D., LUCA, A.C., POPESCU, F., PAVEL, L., GAVRILESCU, C.M., Rev. Chim. (Bucharest), 69, no. 8, 2018. p. 22782282.

49.GHEORGHE, C.G., BONDAREV, A., ONUTU, I., Rev. Chim. (Bucharest), 69, no. 8, 2018, pp. 2045-2049.

50. RUSANESCU, M., RUSANESCU, C.O., VOICU, G., BEGEA, M., Rev. Chim. (Bucharest), 69, no. 7, 2018, pp. 1965-1968.

51.*** SR EN 60068-2-10/2006 Environmental testing. Tests. TestJ and guidance: Mould growth

52. PAPP, B., ERZBERGER, P., ODOR, P., HOCK, Z., SZOVENYI, P., SZURDOKI, E., TOTH, Z., Studia Bot. Hung., 41, 2010, pp. 31-59.

53. LINGVAY, I., LINGVAY, C., CIOGESCU, O., HOMAN, C., Rev. Chim. (Bucharest) 58, no.1, 2007, pp. 44-47.

54. LINGVAY, J., GROZA, C., LINGVAY, C., CSUZI, I., Korroz. Figy., 49, no. 30, 2009, pp. 31-37

Manuscript received: 27.08 .2018 